\title{
ÔNIBUS 174 - IMAGENS DA HUMILHAÇÃO SOCIAL
}

\section{Paulo Roberto Ramos}

Resumo: Este artigo procura debater a psicologia social no cinema através de um conceito específico: a humilhação social como problema político. Para tanto foi tomado como objeto de análise o filme Ônibus 174, documentário realizado pelo cineasta José Padilha em 2002. Os comentários elaborados aqui visam compreender as estratégias narrativas utilizadas pelo diretor, que incluem aspectos estéticos e a participação do público, que transformam sua obra em um objeto de estudo da humilhação social que ocorre no âmbito da esfera pública, onde a ação define as relações sociais entre os indivíduos.

Palavras-chave: Humilhação. Cinema. Psicologia social. Processos sociais.

A todos, en algún momento, se nos ha revelado nuestra existencia como algo particular, intraferible y precioso. Casi siempre esta revelación se sitúa en la adolescencia. El descubrimiento de nosotros mismos se manifiesta como un sabermos solos, entre el mundo y nosotros se abre una impalpable, transparente muralla: la de nuestra conciencia. Es cierto que apenas nacemos nos sentimos solos; pero niños y adultos pueden trascender su soledad y olvidarse de sí mismos a través de juego o trabajo. En cambio, el adolescente, vacilante entre la infancia y la juventud, queda suspenso un instante ante la infinita riqueza del mundo. El adolescente se asombra de ser. Y al pasmo sucede la reflexión: inclinado sobre el río de su conciencia se pregunta si ese rostro que aflora lentamente del fondo, deformado por el agua, es el suyo. La singularidad de ser - pura sensación en el niño - se transforma en problema y pregunta, en conciencia interrogante.

Octavio Paz 


\section{Introdução}

No dia 12 de junho de 2000, um homem tentou assaltar os passageiros de um ônibus no Jardim Botânico, na cidade do Rio de Janeiro. Em pouco tempo o veículo foi cercado pela polícia e pela imprensa, impedindo o rapaz de escapar e transformando um simples caso de roubo em sequestro. $\mathrm{O}$ acontecimento poderia ter passado despercebido, não fosse pela presença da televisão, que acompanhou o fato durante quase cinco horas, transmitindo-o ao vivo para milhões de brasileiros.

O episódio foi retomado pelo cineasta José Padilha em seu documentário Ônibus 174 (Padilha, 2002), uma das mais vigorosas realizações do cinema nacional contemporâneo. $O$ diretor, ao nos apresentar o principal protagonista do evento - o sequestrador Sandro Rosa do Nascimento - utilizou determinadas estratégias estéticas que nos permitem analisar a trajetória de Sandro sob a ótica da humilhação social como problema político.

Um dado que devemos mencionar logo de início e que acreditamos ser fundamental para a análise do filme é que o espectador é um elemento capital na equação do documentário de Padilha. Fazemos esta afirmação porque o diretor emprega elementos da narrativa cinematográfica em sua realização que levam o público para dentro da obra. O filme é sobre Sandro e também sobre nossa relação com ele como espectadores e sujeitos sociais.

\section{Humilhação social como problema político}

Para José Moura Gonçalves Filho' o caráter político da humilhação social ocorre porque esta tem origem na desigualdade de classes. Se a questão econômica está implícita nesta afirmação - é na capacidade de compra e aquisição de bens que se estabelece o mérito do cidadão-consumidor na sociedade capitalista - ela traz em si um elemento político na medida em que a desigualdade se transforma em barreira para a manifestação plena do sujeito no espaço público, fato que transforma a situação do humilhado em algo ainda mais cruel:

A humilhação social conhece, em seu mecanismo, determinações econômicas e inconscientes. Deveremos propô-la como uma modalidade de angústia disparada pelo enigma da desigualdade de classes. Como tal, trata-se de um fenômeno ao mesmo tempo psicológico e político. O humilhado atravessa uma situação de impedimento para sua humanidade, uma situação reconhecível

1 A inspiração deste artigo veio não apenas dos textos de José Moura Gonçalves, mas também durante a disciplina ministrada por ele na pós-graduação do Instituto de Psicologia da USP, no segundo semestre de 2006, onde tive a oportunidade de debater com ele e outros alunos do curso a questão da humilhação social no filme de José Padilha. 
nele mesmo - em seu corpo e gestos, em sua imaginação e sua voz - e também reconhecível em seu mundo - em seu trabalho e em seu bairro (Gonçalves Filho, 1998, p. 13).

Na afirmação de Moura Gonçalves encontramos algumas passagens que gostaríamos de comentar. A primeira delas é quando o autor afirma que a humilhação social é um tipo de angústia que tem origem na desigualdade de classes. A angústia no humilhado surge no momento em que este sente sua humanidade ameaçada. Para Jean Laplanche a angústia é um afeto, ou melhor, é algo que desordena um afeto (Laplanche, 1998). Este desarranjo vem de fora, quando uma pessoa recebe de outra gestos, palavras ou atos que resultam em degradação.

Outro ponto que nos interessa mais de perto é quando ele afirma que o humilhado passa por uma situação de impedimento no momento em que vai a público, ou seja, quando este está no espaço compartilhado de seu trabalho e de seu bairro. A humilhação social ocorre, portanto, na esfera pública. Os processos que colocaram Sandro do Nascimento na situação de um humilhado social ocorreram, segundo o documentário de José Padilha, no espaço público conforme definido por Hannah Arendt em sua obra A Condição Humana (Arendt, 2004).

Arendt define a condição humana por meio da seguinte tríade:labor, trabalho e ação. Os dois primeiros elementos são responsáveis, respectivamente, pela aquisição de produtos essenciais para a garantia da sobrevivência da espécie e à fabricação artificial de produtos que não se encontram na natureza e de certa forma perpetuam a presença efêmera do ser humano sobre a face do planeta.

A ação é o único componente da vita activa cuja atuação não se restringe exclusivamente à natureza, mas sim à vida dos homens em sociedade. É claro que a sociedade não se sustenta sem a presença do labor e do trabalho, mas é justamente esta qualidade comunitária da ação que possibilita o surgimento da atividade política.

Hannah Arendt ensina-nos que a esfera pública é tanto o local onde tudo o que vem a público existe para ser compartilhado pelos indivíduos, quanto o lugar comum a todos nós.

Quando levamos nossas opiniões para o espaço público compartiIhamos nossas experiências com outras pessoas. Este ato simples leva-nos a interagir no campo político, a transformar em práxis nossos pensamentos, pois a idéia colocada em praça pública se transforma em ação. $O$ pensamento, enquanto se restringir ao universo privado, é um conceito abstrato. Ao se deslocar para o campo social, ele se transforma em elemento que colabora para construção do mundo em que vivemos.

Ir a público, no sentido arendtiano do termo, nada tem a ver com o comportamento acrítico da sociedade de massas, onde a atitude de se colocar sob os olhos dos outros nada mais é do que mero espetáculo. Ele é o 
gesto que garante a pluralidade, a diversidade de opiniões e de formas de conduta.

A ação não pode surgir na solidão, pois isolar-se é o mesmo que estar dela privado. Segundo Arendt, o mito do homem forte que adquire sua força pelo fato de estar isolado do resto da humanidade não passa de superstição, baseada na ilusão que podemos fabricar algo na esfera dos negócios humanos da mesma maneira que fazemos cadeiras e mesas. Tratar com homens não é o mesmo que lidar com madeira, aço, cimento.

Retomando o texto de Gonçalves Filho (1998) compreendemos que a humilhação se transforma em um problema político na medida em que ela impede ou ameaça a aparição do sujeito na esfera pública.É quando vai a público, quando está em sociedade que o bloqueio de sua humanidade se torna um fato ainda mais cruel e extremo para o humilhado.

As vozes sem corpo e a tomada de ponto de vista simbólica

Na tela escura, letreiros nos apresentam de imediato o tema do documentário:

Em 12 de julho de 2000, a polícia do Rio de Janeiro cercou um homem que tentava assaltar um ônibus. Ele fez onze reféns e o BOPE foi chamado. O incidente ficou conhecido como o caso do Ônibus 174.

Um corte seco nos conduz para uma sóbria tomada aérea do mar, que lentamente nos guia para a região costeira do Rio de Janeiro. Somos convidados a entrar na cidade pela porta dos fundos, se assim podemos dizer, pois o que vemos não é o célebre litoral formado pelas Avenidas Atlântica e Vieira Souto. Guiados pelo olhar e pela mobilidade do dispositivo, sobrevoamos os morros e suas favelas ao som de uma música solene e pesada que será presença constante nas quase duas horas de projeção da película. Quando o travelling ultrapassa uma favela, que nos impressiona por suas dimensões, a música recua para que algumas vozes possam tomar o primeiro plano sonoro do filme:

Meu nome é Luciana. Moro na rua há 19 anos. Vim para rua com 5, 6 anos. O motivo de eu estar na rua: espancamento. Por parte de quem? Dos meus padrastos, da minha mãe.

Antes da gente vir para a rua a gente era bom de situação sabe, mas meu pai ele era alcoólatra. Eaíminha mãe apanhava muito quando ele bebia e ela foi, fugiu de casa e veio para a rua. 
Pô, posso falar a minha vontade, a minha felicidade legal? Minha felicidade... Acho que não tem mais jeito de eu ser feliz não. Não tenho mais ninguém, não tenho mãe, não tenho pai, não tenho porra nenhuma. Só tenho meus filhos, não tenho mais jeito de ser feliz não.

É um chão gelado, não tem um conforto. Tem um lugar, vê, dorme debaixo da marquise... O pleiboizinho deitado lá em cima, em uma cama, a gente deitado aqui em baixo, no chão. Amanhã de manha levanta e às vezes não tem um café pra tomar, a gente vai para a porta da padaria pedir um café. Às vezes mesmo rouba porque não tem o que comer... Quando cresce, já cresce revoltado.

O Mancha veio para rua criança, cara. Então ele não teve tempo para ter um amor de ninguém entendeu? Então o que ele aprendeu na rua foi sobreviver, mano. Foi o que nós todos aprendemos: é sobreviver por si próprio. Porque se eu for um menor de rua e tiver aqui sentado e não correr atrás ninguém vai aparecer aqui e dar uma comida. Tem que correr atrás mesmo.

Não vemos os rostos que pronunciam estas falas. Deduzimos que são depoimentos de pessoas que moraram ou que ainda continuam vivendo nas ruas. Até este instante nada mais podemos concluir, exceto que estas vozes são discursos sem corpo, pois o filme ainda não associou a elas uma imagem. A câmera continua planando sobre a cidade e sua leveza nos coloca numa posição confortável, tranquila. Observamos tudo de um ponto privilegiado - o do espectador ou do "turista visual" distanciado que passeia pelas mais diversas regiões do Rio de Janeiro sem estar no interior de suas ruas, de seu intrincado espaço urbano.

Das imagens das favelas passamos para uma região com piscinas, quadras de tênis e de outros esportes rodeadas por casas e edifícios que respiram um espaço que os morros apresentados anteriormente não podem dispor. Isto ocorre aproximadamente entre o terceiro e o quarto depoimentos transcritos acima. Neste instante escutamos ao fundo transmissões de um rádio de polícia e o som de um helicóptero. Mais uma vez um personagem é introduzido por meio de sua voz:

Eu tive noticia pelo radio, da viatura administrativa em que estava, de que o $B O P E$ estava sendo acionado para uma ocorrência com reféns no Jardim Botânico. Eu imediatamente liguei pro comandante da unidade e me coloquei à disposição, para que primeiro chegasse ao local como forma de avaliar em que condições o evento já se encontrava.

Na última frase pronunciada acima pelo policial, o longo travelling chega ao fim e se detém por alguns instantes num ponto turístico inconfundível na paisagem carioca: o Pão de Açúcar. Em seguida, temos pela primeira vez no documentário a sincronização entre uma voz e o indivíduo 
que a pronuncia. O homem da lei continua seu depoimento: "Então ele autorizou e eu, da ponte Rio Niterói, tomei caminho do Jardim Botânico e fui o primeiro a chegar no local."

A segunda pessoa a ter sua fala associada simultaneamente à sua imagem é um repórter:

A TV começou a passar imagens captadas da CET Rio... A imagem era: tenho um ônibus cercado no Jardim Botânico, parece que um rapaz, um assaltante, mantém passageiros com reféns. Imediatamente o jornal então mandou, quase toda a equipe foi deslocada para lá.

Um corte seco nos leva para uma tela escura onde vemos impresso, em letras brancas, o título do filme - Ônibus 174.

A sequência de abertura descrita acima representa quase cinco minutos de projeção. Nela encontramos elementos fundamentais para a compreensão do documentário de José Padilha.

O curto parágrafo que abre o filme nos informa, com a precisão e objetividade de um texto jornalístico, a data e o local do evento. Erroneamente o letreiro nos leva a pensar que teremos pela frente um tradicional documentário sobre o sequestro de um ônibus, com aquelas enfadonhas reconstituições dos fatos e depoimentos insossos. Logo abandonamos esta atitude, na medida em que ouvimos os depoimentos dos meninos de rua enquanto a câmera dá seu passeio aéreo sobre a cidade. Esperamos ver os rostos dos depoentes, condicionados que estamos às tradicionais entrevistas dos jornais e programas de televisão, mas o filme nos nega isso. Perguntamos então qual a razão da câmera assumir uma posição distanciada e por que apenas ao policial e ao jornalista é dado o direito da sincronização de suas imagens e suas vozes. Arriscamos uma resposta: isto ocorre porque os elementos formais da linguagem cinematográfica adotados pelo cineasta se constituem numa tomada de ponto de vista que assume simbolicamente o olhar das classes mais instruídas e economicamente meIhor posicionadas na sociedade brasileira e que seguramente constituem a maior parte dos espectadores que estão na sala de cinema assistindo ao documentário de Padilha.

Edward Branigan define a tomada de ponto de vista como aquela onde a câmera assume a posição de um sujeito para nos mostrar o que ele vê (Branigan, 1985). Este plano pode ser objetivo, assumindo a posição de um personagem fisicamente presente numa cena, ou pode ser metafórico, como o ponto de vista do predador marinho em Tubarão de Steven Spielberg, do computador de 2001, Uma Odisséia no Espaço de Stanley Kubrick ou dos leões de $A$ Sombra e a Escuridão de Stephen Hopkins. 
Como afirmamos acima, a câmera na sequência inicial de Ônibus 174 assume o olhar metafórico de uma classe social. Uma das características desta classe é que na maioria dos casos ela se relaciona com as classes pobres e com infratores, como Sandro Nascimento, através das janelas de seus automóveis ou por meio das telas do cinema e da televisão. Os excluídos se tornam visíveis para as classes privilegiadas somente quando se colocam diante dos carros que param nos semáforo ou das câmeras que capturam suas imagens para transmiti-las para os aparelhos de televisão ou para projetá-las nas salas de cinema.

Se nos automóveis a proximidade física com o outro pode causar certa ameaça, nas salas de estar ou nos cinemas as imagens reproduzidas são absolutamente tranquilizadoras, pois o espectador jamais é ameaçado pela presença que surge na tela. E mesmo neste caso, se algum incômodo surgir, basta apertar uma tecla do controle remoto ou simplesmente deixar o local de projeção do filme.

Mencionamos também que os depoimentos dos meninos de rua não são acompanhados por suas respectivas imagens e que os primeiros personagens a terem seus discursos associados a seus corpos são aqueles que poderíamos chamar de "intermediários", ou seja, as pessoas a quem "delegamos" o contato com infratores como Sandro: a polícia e a imprensa. $\mathrm{Na}$ abertura do documentário notamos que o espaço urbano carioca exibido pela câmera é correspondido pela classe social a que os depoentes pertencem ou representam. Ela sobrevoa as favelas quando falam os meninos de rua e passa sobre piscinas e quadras de tênis no momento em que o policial inicia seu discurso. A última cena que vemos é a do Pão de Açúcar, a imagem oficial da cidade e seu cartão postal para turistas de outras partes do Brasil e do mundo. Ela é a imagem simbólica daquilo que a polícia deve proteger e que os meios de comunicação deveriam divulgar.

A sequência de abertura nos leva ao texto clássico sobre a perspectiva como forma simbólica de Erwin Panofsky. Para o autor a perspectiva pictórica tem dupla função: ao mesmo tempo em que produz um afastamento dos seres e das coisas, ela cria uma aproximação ao fazer chegar até o olhar do observador as cenas, os objetos e as figuras do mundo (Panofsky, 1999). Ônibus 174 trilha esse tênue caminho ao tentar aproximar um mundo de excluídos dos olhares daqueles que geralmente estão distantes dele - os espectadores das salas de cinema.

A opção empregada pelo cineasta de afastar as vozes dos jovens moradores de rua de seus corpos é uma representação da invisibilidade

3 Em Notícias de uma Guerra Particular (João Moreira Salles e Kátia Lund - 1998/99) Hélio Luz chefe da polícia civil do Rio de Janeiro - deu o seguinte depoimento: "A polícia foi feita para fazer segurança de estado e segurança da elite... É uma polícia política mesmo. Isso aqui é uma sociedade injusta e nós garantimos essa sociedade injusta. O excluído fica sob controle. Ele que saia disso! Enós fazemos um negócio bem sofisticado. Na África do Sul eles colocam arame, aqui é sem arame". 
que estes vivem na esfera pública, situação mencionada explicitamente no documentário por Luiz Eduardo Soares. Estes meninos não são sujeitos sociais, eles são reconhecidos pela esmagadora maioria da população apenas pelos estereótipos a eles atribuídos.

José Moura Gonçalves aponta na invisibilidade uma das nove situações sentimentais da humilhação social. As oito restantes são as seguintes: sentimento da cidade, dos lugares públicos como expulsivos; sentimento dos bens públicos como amargos; sentimento de invisibilidade ou superexposição; sentimento de estar sob contínua vigilância, sempre na iminência de sofrer comandos ou reprovação; sentimento de não possuir direitos; sentimento de fealdade; sentimento de privação e incompetência, resultando em um sentimento permanente de si próprio como de um carente; sentimento de impedimento, de uma vida que nunca chega a perfazer seus ciclos; sentimento de vergonha. Esta condição de não serem reconhecidos como seres humanos transformam meninos de rua como Sandro e outros indivíduos excluídos da sociedade em seres famintos por reconhecimento social, como afirmou Luiz Eduardo Soares em seu depoimento para Ônibus 174. Em tais situações o ser humilhado se assemelha aos homens ocos de T.S.Eliot:

\author{
Nós somos os homens ocos \\ Os homens empalhados \\ Uns nos outros amparados \\ O elmo cheio de nada. Ai de nós! \\ Nossas vozes dessecadas, \\ Quando juntos sussurramos, \\ São quietas e inexpressas \\ Como o vento na relva seca \\ Ou pés de ratos sobre cacos \\ Em nossa adega evaporada
}

Fôrma sem forma, sombra sem cor,

Força paralisada, gesto sem vigor.

Sandro é um indivíduo cuja posição na sociedade o tornou invisível no espaço da esfera pública. José Padilha constrói a representação da negação, por parte da sociedade, da aparição dos sujeitos marginalizados. Negação que os transforma em abstrações. Mais uma vez recorremos a Gonçalves Filho (1998) que afirma que viver de modo abstrato é viver na reificação, é estar em um mundo onde as aparências estão bloqueadas. A aparição "encontra condições materiais apenas numa comunidade de homens livres, iguais e singulares" (Gonçalves Filho, 1998, p. 48). O que Ônibus 174 procura fazer é fornecer elementos que nos permitam reconhecer em seu protagonista uma humanidade que o meio social em que vivia Ihe recusou. 


\section{A sequência inicial e as crises brasileiras no cinema}

Em 1967, Glauber Rocha levou para as telas Terra em Transe. Obra fundamental de nossa cinematografia, o filme procura compreender a nova realidade nacional depois de três anos da tomada do poder pelos militares, que impôs à nação um governo ditatorial que durou pouco mais de duas décadas. Em seu início encontramos uma tomada aérea do mar acompanhada pela música de um ritual de umbanda, significando o transe e a crise política de uma nação do terceiro mundo às vésperas de um golpe de estado. Sobre essa sequência Ismail Xavier fez o seguinte comentário:

Lá no início, há o longo plano que nos leva do Oceano Atlântico ao país alegórico, Eldorado; lento deslocamento da câmera aérea divisando o mar e, em seguida, chegando à costa do país tropical nomeado no letreiro. $O$ som do ritual africano pontua esta lenta chegada, como uma emanação da terra que se aproxima e se mostra, de início, pelas praias, pelos morros da costa... Define-se uma geografia, conota-se, pela pletora solar, a configuração tropical deste mundo em que estamos prestes a mergulhar. Antes, portanto, de nos situarmos frente ao drama histórico vivido pelos habitantes de Eldorado, compõe-se esta moldura que posiciona, pelo longo plano da natureza e pela música que o marca, esta parte do mundo que ora se avizinha dentro de uma ordem planetária: não devemos nos esquecer do calor, da luz ofuscante, da atmosfera, do tipo de cultura que um certo imaginário associa a este quadro geográfico. (Xavier, 1993, pp.58-59)

Portanto, as introduções de Ônibus 174 e Terra em Transe apresentam a mesma tomada aérea que conduz o espectador do mar para a praia. Os dois planos de abertura nos levam a um Brasil em crise. Em Rocha a articulação de som e imagem - o ponto de umbanda e a visão do litoral - resulta na representação alegórica do transe de um país subjugado por um regime de exceção e do olhar estereotipado de uma nação tropical. No documentário de José Padilha, o longo plano inicial, com sua música solene e sombria muito próxima dos programas sensacionalistas da televisão, também nos conduz para um país que continua vivendo sob o signo da crise. Esta, no entanto, não é de caráter político-institucional. Ela é o resultado da violência urbana que tomou de assalto o país após o término da ditadura (Zaluar, 1998).

Ônibus 174 nos permite fazer ligações com outros filmes. Um deles é Notícias de uma Guerra Particular (1999), documentário de João Moreira Salles e Kátia Lund, onde também encontramos as tomadas aéreas do Rio de Janeiro e um música solene da trilha sonora. Além disso, algumas imagens de Notícias foram utilizadas por José Padilha em seu filme.

Outra associação que fazemos por nossa conta e risco não diz respeito propriamente a um filme, mas sim às produções da Miramax. No início das fitas realizadas por esta empresa norte-americana, uma pequena se- 
quência animada exibe uma cena que vai do mar para o litoral mostrando uma cidade noturna - provavelmente Nova York - onde as luzes dos prédios aos poucos se acendem até se transformarem lentamente no nome da companhia.

\section{Cidadão Kane e Ônibus 174 - a construção mediada dos personagens e os poderes da câmera}

Cidadão Kane (1941) de Orson Welles é talvez a maior influência de Ônibus 174. Tal afirmação, que à primeira vista parece ser arriscada, é feita aqui por duas razões: a atribuição de poderes sobre-humanos a câmera e a estrutura narrativa em flash back da obra máxima do cineasta norteamericano que procura compreender, por meio de vários depoimentos, a vida de seu protagonista.

Nos primeiros momentos de Kane a câmera se dirige a uma cerca onde se depara com um aviso: "No trespassing" - "não ultrapassar". Alheia aos dizeres da placa ela avança, passa por sobre a cerca e se dirige a um castelo localizado no topo de uma colina, onde a luz branca de uma janela contrasta com o ambiente sombrio dos jardins da mansão, com seus animais, gôndolas e estátuas. Em sua análise do filme de Welles, David Bordwell afirma que sua câmera é dotada de um poder ubíquo:

O cinema é um aperfeiçoamento da visão porque o olho da câmera, ao contrário do olho do espectador, não pode ser impedido por cercas, paredes ou sinais. Se alguma coisa interfere com seu progresso seguro no interior de uma cena, sabemos que esta coisa é um obstáculo artificial e temporário. (Bordwell, 1976, p. 275)

Durante este trajeto a janela iluminada parece atrair a câmera em seu percurso. Justamente quando ela nos coloca diante da janela, a música atinge um clímax e a luz se apaga. Um corte suave nos leva para o interior de um quarto, que supomos ser aquele da referida janela, onde uma figura humana jaz em seu leito. Delicadamente a neve parece cair sobre o recinto, mas logo percebemos que se trata de uma gentil fusão das imagens de neve caindo dentro de uma bola de vidro, daquelas de brinquedo, com uma casa em miniatura em seu interior. A leveza, que dominou tudo o que vimos até o momento, coloca em primeiríssimo plano lábios que sussurram uma única palavra:"Rosebud". O globo desprende-se da mão que o segurava e se estilhaça no chão. Uma enfermeira entra no recinto e de forma gentil cobre o homem que acabou de falecer.

Retornamos para a mesma cena da janela com o corpo deitado na cama. Mais uma suave fusão e toda a tranquilidade que marcou esta belíssima sequência é bruscamente interrompida por uma música estridente e pela voz de um narrador que anuncia com estardalhaço:"News on the 
march"! É o início de um cinejornal que relata, de forma resumida, a vida de Kane.

Além de nós, os espectadores, o jornal está sendo visto dentro do filme por uma pequena platéia de jornalistas, onde um dos repórteres é incumbido de desvendar o mistério de Rosebud, última palavra pronunciada por Kane em seu leito de morte. O que chama atenção aqui é que não havia ninguém no quarto de Charles Foster Kane que ouviu sua última palavra pronunciada em vida. $E$, no entanto, parece perfeitamente normal para nós que os jornalistas souberam qual era ela. Como nos deixamos levar por este pequeno truque de Welles? Possivelmente é a tomada em primeiríssimo plano dos lábios, que se tornam imensos na tela, que nos dá a ilusão que Rosebud parece ter sido dita para os quatro quantos do mundo. É o olhar potente da câmera que nos leva a pensar que seria natural que alguém mais na trama urdida no filme tivesse ouvido a última palavra de Kane.

Durante o filme acompanhamos um destes jornalistas em sua investigação que o levará a produzir sua reportagem sobre o personagem. Seremos guiados pelo olhar deste jornalista, que atuará como nosso representante durante o filme. Testemunhamos as leituras de memórias e entrevistas de pessoas que tiveram contato com o magnata - seus amigos, sua ex-mulher, seu tutor. Tudo isso com o propósito de descobrir o significado de uma única palavra, que uma vez decifrado, possibilitará montar um quebra-cabeça que permitirá desvendar os segredos de uma vida. É possível expressar o que foi a vida de um indivíduo por meio de uma única palavra?

Ônibus 174 apresenta a mesma estrutura. Em seu longo plano de abertura temos uma câmera onipotente que atravessa distâncias, rompe fronteiras e aproxima elementos que raramente se encontram no cotidiano carioca - as favelas do morro e as ruas da cidade, a Zonas Norte e Sul. No desenrolar da narrativa chegam até nós depoimentos de companheiros de rua de Sandro, de sua tia, de uma mulher que exerceu tardiamente para ele o papel de mãe adotiva, de assistentes sociais, de policiais, dos reféns e de jornalistas que cobriram o sequestro. É por meio dessas entrevistas e de documentos feitos pelas autoridades ${ }^{4}$ que o cineasta constrói a trágica biografia de Sandro do Nascimento: a criança que presenciou o brutal assassinato de sua mãe, o menino de rua que sobreviveu ao massacre da

4 Um desses documentos apresentados no filme é da Secretaria de Estado da Justiça e Interior - Setor Serviço Social / Psicologia. Nele encontramos as seguintes passagens: "Sandro Rosa do Nascimento, idade 16 anos, apresenta lesões corporais. Não reside com a família. Adolescente está na rua. Tem parado na Zona Sul. Não lembra há quanto tempo. A mãe é falecida há anos. Antes morava com a tia materna (Jú). Não conheceu o pai. Tem dois irmãos. Estão um com a tia e outro com avó. OBS: adolescente bastante resistente em prestar informações sobre sua situação social, dizendo que não se lembra das coisas porque tem problemas demais na cabeça, mas não quer falar sobre estes problemas".

PsICologia USP, São Paulo, outubro/dezembro, 2009, 20(4), 639-655. 
Candelária ${ }^{5}$, o rapaz que passou por várias instituições prisionais do Rio de Janeiro e o homem cercado pela polícia e pela imprensa dentro do ônibus no Jardim Botânico.

Nas diversas opiniões sobre Sandro que desfilam diante de nosso olhar, o filme constrói um personagem rico, que não pode ser reduzido a uma opinião moldada por preconceitos e estereótipos. O cineasta nos convida a elaborar nossa própria perspectiva e ir um pouco além das janelas dos automóveis, dos aparelhos de TV e das telas de cinema que tradicionalmente se abrem para o universo dos muitos Sandros que povoam as esquinas e cruzamentos de nossas cidades.

A aparição de Sandro do Nascimento em Ônibus 174 é duplamente mediada, pois ele é apresentado através das imagens produzidas pelas redes de televisão que cobriram o evento e por meio dos depoimentos de pessoas entrevistadas no filme que falam sobre ele. Nos dois casos a câmera é o dispositivo que se interpõe entre Sandro e o espectador. No entanto, ao utilizar cenas da mídia em seu documentário José Padilha desnuda os mecanismos normalmente empregados por ela quando a mesma volta sua atenção para as classes pobres e excluídas.

Os indivíduos das classes menos favorecidas são habitualmente retratados pela imprensa - rádio, TV e jornais - de forma estereotipada. Eles não são apresentados como pessoas, mas como certos tipos sociais - meninos de rua, favelados, bandidos, desocupados. Este olhar sobre os pobres foi assim definido por Silvia Leser de Mello (2004):

Através das imagens e das palavras eles são fotografados e rotulados. Não se veem mais pessoas.Elas tornaram-se rótulos:veem-se carentes,favelados,ladrões, menores infratores, delinquentes, criminosos, bandidos, viciados. Dar ao público um esclarecimento sobre o ato violento deveria ser o papel da mídia. Bem como não prejulgar seus atores, classificando-os e rotulando-os, ou apresentá-los de maneira ridícula, atentando contra sua dignidade. Incitar à vingança, identificar segmentos da população como portadores da maldade pelo simples fato de serem pobres, gira ainda uma vez a roda da violência e não beneficia ninguém. (Mello, 2004, p. 139).

Segundo Ecléa Bosi os mecanismos de recepção dos fatos e das situações sofrem influências de um recorte e estão condicionados pela cultura, o que pode levar a um processo que resulta em estereótipo (Bosi, 2003). Bosi acrescenta também que nem sempre estamos abertos à percepção, pois nossa insensibilidade e desatenção em relação às coisas do mundo podem causar um empobrecimento que nos leva a olhar através de me-

5 O massacre da Candelária ocorreu na madrugada do dia 23 de junho de 1993, quando oito jovens moradores de rua foram violentamente assassinados por policiais militares enquanto dormiam na frente da igreja da Candelária. Sandro foi uma das crianças que escapou desta chacina. 
diações impostas. Este é normalmente o comportamento da mídia e de seus espectadores anestesiados.

Todavia, Sandro utiliza esta imprensa que sempre lhe é desfavorável. Ele sabe que seus poderes não são nada desprezíveis. Por um breve momento ele se utiliza desta força para encenar sua tragédia. No interior do ônibus, Sandro percebe as câmeras de televisão que o cercam - lembremos que para sua segunda mãe havia manifestado seu desejo de se tornar artista.É para elas que ele elabora sua representação. Ele orienta os sequestrados para "atuarem diante das câmeras", levando-os ora a parecerem desesperados, ora a escreverem mensagens nos vidros do veículo. Neste pequeno teatro ele devolve aos espectadores algo que sempre ignoraram: sua face. Segundo Esther Hamburger:

O interior do ônibus, onde nem tudo pode ser visto ou ouvido, se torna como que um bastidor para o que se configura como uma verdadeira atuação dramática. Sandro foi ator. Ao longo do evento foi encarnando um personagem homemmal, para o qual seu perfil era adequado (Hamburger, 2005, p. 204)

A relação entre o protagonista e a câmera é mencionada por outros personagens do filme:

Acho que a televisão permitiu que ele se sentisse poderoso, na medida em que ele sabia que estava sendo filmado e queria ser filmado. (outra refém de Sandro)

Ele jogou muito bem jogado. Mas ele sabia o que iria acontecer se ele fosse pego. Então era a maneira dele também se proteger. (Yvonne Bezerra de Mello)

A mídia é algo que traz confiança ao sequestrador. Lógico! É a certeza que não vou ser executado, morto! (Rodrigo Pimentel ${ }^{6}$ )

O prolongamento daquela situação também servia como um espaço de significar alguma coisa para alguém, como um espaço de mostrar que ele tinha poder, de mostrar que ele existia, enfim. E isso era uma coisa tão fundamental quanto resolver a situação de sair dali vivo. Então as câmeras de televisão importavam para ele. (Outra refém)

No entanto, não é somente Sandro quem se dirige para as câmeras de televisão. Uma das reféns é escolhida por ele para escrever nos vidros do ônibus mensagens para os espectadores que circundam o veículo. Deixemos o que ela nos conta como aconteceu:

6 Rodrigo Pimentel e que atuava no Batalhão de Operações Especiais - BOPE - na época do caso do ônibus 174. Pimentel foi um dos principais depoentes de Notícias de uma Guerra Particular e é um dos roteiristas de Tropa de Elite (2007) de José Padilha. 
Ele estava mexendo em uma das bolsas e pegou o batom. Ele mesmo me deu o batom. E aí ele me chamou: "Vem cá mocinha, vem cá escrever na frente do ônibus".

Não sei o que me deu na cabeça na hora de falar assim: Ah, vou escrever para todo mundo lá fora ver. Não sei se foi a presença de espírito, o que foi, alguma coisa que me disse: "Escreve ao contrário". Porque na brincadeira você escreve ao contrário, mas com uma arma na cabeça não é tão simples.

Este relato é seguido pela opinião de um policial:

O grau de violência dele está associado diretamente à presença das câmeras. Ele sim estava preocupado em aparecer, em representar a peça dele.

A seguir, a palavra é dada mais uma vez à moça das mensagens com batom. É quando descobrimos que ela também "representava" para a câmera: "Tive a sensação que o mundo estaria vendo aquilo, que seria retransmitindo".

É importante mencionar que neste instante a câmera retoma seu passeio aéreo para nos mostrar as torres de transmissão de TV instaladas no alto de uma montanha. Essas torres parecem submeter a cidade ao seu poder. São construções metálicas que, tomadas em primeiro plano, parecem dominar a paisagem subjugando até mesmo referências importantes do Rio de Janeiro, como o Pão de Açúcar e o Cristo Redentor, que permanecem, durante esta tomada, reduzidos ao segundo plano.

As câmeras de televisão representam para Sandro um breve momento de ruptura em relação à sua invisibilidade social. Mas ele sabe que seu afastamento delas trará consequências terríveis, como podemos constatar na última parte do documentário. Ao mesmo tempo em que elas são instrumentos de seu reconhecimento, elas indiretamente representarão sua morte, como podemos notar no depoimento de Yvonne Bezerra de Mello transcrito acima.

\section{Comentários finais}

Reconhecemos na trajetória de Sandro do Nascimento reconstituída em Ônibus 174 outros elementos da humilhação social apontados por José Moura Gonçalves Filho: a impressão de estar sob contínua vigilância, sempre na iminência de sofrer comandos ou reprovação; a certeza de não possuir direitos; o sentimento de privação e incompetência que leva a uma visão de si próprio como a de um indivíduo carente; sentimento de impedimento, de uma vida que nunca chega a perfazer seus ciclos. Retomando a epígrafe deste artigo, o rosto que Sandro via no rio de sua consciência era uma face solitária. Sua singularidade não se transformou em uma consciência questionadora. Ela não foi além do vazio abissal de um processo 
extremo de exclusão. $O$ resultado foi cruel, tanto para ele quanto para as vítimas de sua violência.

Depois de pouco mais de duas horas de exibição temos a certeza que Ônibus 174 apresentou-nos seu personagem. Para Antonio Cândido o personagem é o que há de mais vivo no romance e que há uma relação direta de dependência entre a leitura deste e a aceitação da verdade do personagem por parte do leitor (Cândido et al., 1995). A construção feita pelo cineasta permitiu que compreendêssemos um pouco mais as razões e os mecanismos sociais presentes na biografia de Sandro do Nascimento. Se os telejornais, em sua guerra por audiência, tendem muitas vezes para o sensacionalismo e a exploração banal e superficial dos acontecimentos, José Padilha caminhou em sentido contrário. Na máscara do tubo de tv o rosto de Sandro se transformava em outra máscara, em caricatura. Na tela de cinema, Padilha devolveu-Ihe seu rosto. Segundo Emmanuel Lévinas (1993):

O fenômeno que é a aparição do Outro, é também rosto; ou ainda (para mostrar esta entrada, a todo instante, nova na imanência e na historicidade essencial do fenômeno): a epifania do rosto é visitação. Enquanto o fenômeno já é, seja a que título for, imagem, manifestação cativa de sua forma plástica e muda, a epifania do rosto é viva. (Lévinas, 1993, p. 51)

\title{
Bus 174 - images of social humiliation
}

\begin{abstract}
This article presents a discussion about social psychology in the cinema through a specific concept:the social humiliation as a political problem. For this was taken as an object of analysis the film Bus 174, documentary directed by José Padilha in 2002. The comments produced here aim to understand the narrative strategies used by the director, which include aesthetic aspects and the participation of the public, that turn their work into an object of study of the social humiliation that occurs within the public sphere, where the action defines social relations among individuals.
\end{abstract}

Keywords: Humiliation. Motion pictures. Social psychology. Social processes.

\section{Omnibus 174 - images de l'humiliation sociale}

Résumé: Cet article a pour bout discuter la psychologie social dans lê cinéma aux yeux d'un concept spécifique: I'humiliation sociale come un probléme politique. Pour aborder ce théme on a pris comme objet d'analise le film «Omnibus 174», un documentaire realisé par le directeur José Padilha, dans l'année de 2002. Les commentaires elaborés ont pour but la compréhensio des stratégies utilisées 
pr le cineaste, qui montre les aspects esthétiques et la participation du publique, que transforment son film dans un objet d'étude de I'humiliation sociale, que aparait das la sphere public, oú l'action défine les rapport sociaux parmi les individus.

Mots clés: Humiliation. Cinéma. Psychologie sociale. Processus sociaux.

\section{Autobús 174 - imágenes de la humillación social}

Resumen: Este artículo presenta una discusión sobre la psicología social en el cine a través de un concepto específico: la humillación social como un problema político. Para esto se tomó como objeto de análisis la película Bus 174, documental dirigido por José Padilha en 2002. Los comentarios aquí producidos tienen por objetivo entender las estrategias narrativas utilizadas por el director, que incluyen aspectos estéticos y la participación del público, en que transforman su obra en un objeto de estudio de la humillación social que se produce dentro de la esfera pública, donde la acción define las relaciones sociales entre los individuos.

Palabras clave : Humillación. Cinema. Psicologia social. Procesos sociales.

\section{Referências}

Arendt, H. (2004). A condição humana. Rio de Janeiro: Forense Universitária.

Bordwell, D. (1976). Citizen Kane. In B. Nichols (Ed.), Movies and methods (Vol. 1, pp. 273-290). Berkeley: University of California Press.

Bosi, E. (2003). Entre a opinião e o estereótipo. In E. Bosi, O tempo vivo da memória (pp. 113-123). São Paulo: Ateliê Editorial.

Branigan, E. (1985). The point-of-view shot. In B. Nichols, Movies and methods (Vol. 2, pp. 672-691). California: University of California Press.

Cândido, A., Rosenfeld, A., Prado, D. A., \& Gomes, P. E. S. (1995). A personagem de ficção. São Paulo: Perspectiva.

Gonçalves Filho, J. M. (1998). Humilhação social - problema político em psicologia. Psicologia USP, 9(2), 11-67.

Hamburger, E. (2005). Políticas da representação: ficção e documentário em Ônibus 174. In A. Labaki \& M. D. Mourão, O cinema do real (pp. 196-215). São Paulo: Cosac Naify. 
Laplanche, J. (1998). A angústia. São Paulo: Martins Fontes.

Lévinas, E. (1993). Humanismo do outro homem. Petrópolis, RJ: Vozes.

Mello, S. L. (2004). A violência urbana e a exclusão dos jovens. In B. Sawaia, As artimanhas da exclusão: análise psicossocial e ética da desigualdade social (pp. 129140). Petrópolis, RJ: Vozes.

Padilha, J. (Diretor). (2002). Ônibus 174 [DVD]. Brasil: LK-TEL Vídeo.

Panofsky, E. (1999). A perspectiva como forma simbólica. Lisboa: Edições 70.

Xavier, I. (1993). Alegorias do subdesenvolvimento: cinema novo, tropicalismo, cinema marginal. São Paulo: Brasiliense.

Zaluar, A. (1998). Para não dizer que não falei de samba: os enigmas da violência no Brasil (pp. 245-318). In L. M. Schwarcz (Org.), História da vida privada no Brasil: contrastes da intimidade contemporânea. São Paulo: Companhia das Letras.

Paulo Roberto Ramos, Doutor em Psicologia Social pelo Instituto de Psicologia da Universidade de São Paulo, Rua Matheus Garcia, 901, Vila Irmãos Arnoni, CEP: 02374000, São Paulo, SP.Endereço eletrônico: paulo@iee.usp.br 